\title{
The anatomy and functional morphology of Diplodon rhombeus fontainianus (Orbigny, 1835) (Mollusca Bivalvia, Hyriidae)
}

\author{
Avelar, WEP. ${ }^{\mathrm{a} *}$ and Cunha, AD. ${ }^{\mathrm{b}}$ \\ ${ }^{a}$ Departamento de Biologia, Faculdade de Filosofia Ciências e Letras de Ribeirão Preto, \\ Universidade de São Paulo - USP, \\ Av. Bandeirantes, 3900, CEP 14049-901, Ribeirão Preto, SP, Brazil \\ bPrograma de Pós Graduação em Biologia Comparada, \\ Universidade de São Paulo - USP, \\ Ribeirão Preto, SP, Brazil \\ *e-mail: waavelar@ffclrp.usp.br
}

Received June 6, 2008 - Accepted September 24, 2008 - Distributed November 30, 2009

(With 9 figures)

\begin{abstract}
Diplodon rhombeus fontainianus (Orbigny, 1835), belongs to the family Hyriidae Swainson 1840, the distribution of which is restricted to South America and Australasia. This species, endemic to Brazil, occurs in the central-southern geographical region, Upper Paraná Basin and Atlantic Microbasins Espirito Santo to Paraná states. The mollusk lives buried in muddy substrata, has similar sized adductor muscles, and is dioecious, lacking sexual dimorphism. The apertures are simple (type AII of Yonge, 1948, 1957) as in Diplodon rotundus gratus, Castalia undosa martensi, Castalia undosa undosa and mantle fusion is present only in the base of the exalant aperture. The inhalant aperture exhibits tentacles originating from the inner fold while the exhalant aperture has no tentacles. The ctenidia are type D (of Atkins, 1937). A well-developed marsupium is present in the inner demibranch. The association between the ctenidia and the labial palps belongs to category I (of Stasek, 1963). The stomach constitutes a type IV structure (of Purchon, 1958). The posterior sorting area (psa) presents two pouches in Diplodon rhombeus fontainianus. Among the Hyriidae, the presence of these pouches has also been described in several species of Hyriidae from South America. The organization of the gut in the visceral mass follows the same pattern seen in the Hyriidae already studied: Castalia undosa martensi, Castalia undosa undosa, Diplodon.rotundus gratus, Diplodon charruanus and Diplodon pilsbryi.
\end{abstract}

Keywords: Bivalvia, Hyriidae, Diplodon rhombeus fontainianus, functional anatomy.

\section{Anatomia funcional e morfologia de Diplodon rhombeus fontainianus (Orbigny, 1835) (Bivalvia: Hyriidae)}

\begin{abstract}
Resumo
Diplodon rhombeus fontainianus (Orbigny, 1835) pertence à família Hyriidae Swainson 1840, cuja distribuição restringe-se à América do Sul e Austrália. A espécie, endêmica no Brasil, ocorre na região Centro Sul, na bacia superior do Paraná e microbacias da costa atlântica do Estado do Espírito Santo até o Estado do Paraná. Os moluscos vivem enterrados em substratos lodosos, têm os músculos adutores aproximadamente do mesmo tamanho, são dióicos faltando dimorfismo sexual. As aberturas são simples, tipo AII de Yonge $(1948,1957)$ semelhantes a Diplodon rotundus gratus, Castalia undosa martensi, Castalia undosa undosa e a fusão do manto ocorre apenas na dobra interna na base da abertura exalante. A abertura inalante exibe tentáculos de origem da dobra interna e a exalante não possui tentáculos. Os ctenídios são do tipo D (de Atkins, 1937). O marsúpio, presente na demibrânquia interna, é bem desenvolvido. O estômago pertence ao tipo IV (de Purchon, 1958). A área de triagem posterior (psa) em Diplodon rhombeus fontainianus é caracterizada pela presença de duas bolsas. Entre os Hyriidae, estas bolsas foram descritas em várias espécies presente na América do Sul. A organização do intestino na massa visceral segue o mesmo padrão visto em Hyriidae já estudados tais como: Castalia undosa martensi, Diplodon delodontus wimanii, Diplodon rotundus gratus, Castalia undosa martensi, Diplodon charruanus, Diplodon pilsbryi e Castalia undosa undosa.
\end{abstract}

Palavras-chave: Bivalvia, Hyriidae, Diplodon rhombeus fontainianus, anatomia funcional. 


\section{Introduction}

The Unionoida, commonly known as freshwater pearly mussels or naiads, is a diverse order of bivalved mollusks and comprised of over 150 genera and spread widely throughout all continents except Antarctica. The Unionoida is an ancient, cosmopolitan, strictly continental group of freshwater bivalve occurring in various freshwater habitats (Burky, 1983; Tevesz and Carter, 1980; Graf and Cummings, 2006).

As to the systematics of the freshwater bivalves, and particularly with respect to the genera and species, opinions diverge markedly. According to Mansur (1970), most systematic studies have employed data from the shell surface, leading to a large, disordered number of species and synonymies; in fact, the modifications observable in the shell probably reflect ecological variation. Thus, freshwater bivalves are particularly difficult to identify, owing to their ample shell variability, and to the different types of environments in which they occur.

The genus Diplodon is considered the most primitive of the South American Hyriidae (Bonetto 1962). Bonetto (1967) noted the difficulty of taxonomic studies on Diplodon species owing to their considerable shell variation, and to the different habitats where they occur. The ample variability in shell shape has generated much discussion regarding the number of species and their synonymies (Bonetto, 1961; 1964; Alvarenga and Ricci, 1977; Mansur and Anflor, 1981).

Diplodon fontainianus (Orbigny, 1835) was originally described as Uniofontainianus Orbigny, 1835. Bonetto (1961) considered the species to be $D$. fontainianus, but later (Bonetto, 1964) included it as a subspecies of Diplodon rotundus Wagner, 1827. Posteriorly Bonetto (1967) refered $D$. rotundus and D. rhombeus, as distinct species, and concluded that there are two well-defined subspecies: D. rhombeus rhombeus and D. rhombeus fontainianus. Bonetto and Mansur (1970), based on studies of the Senckenberg museum collections (Germany), maintained the identification proposed by Bonetto (1967). Bonetto and Mansur (1970), analysing bivalves collected from the Guaíba river basin, encountered a wide range of variation in the animals examined, especially in the form and the different degrees of convergence of the central rib sculpture. Many authors, including Simone (2006) consider D. fontainianus to be a valid species with "rhombeus" in a different genus.

The aim of the present investigation was to examine the structure, ciliary currents for feeding and digestion, and other functional adaptations of D. rhombeus fontainianus supplying morphological and functional subsidies for future knowledge and phylogenetic position of South American Hyriidae.

\section{Material and Methods}

Live specimens of Diplodon rhombeus fontainianus (Figure 1) were collected from the Pardo River in the municipalities of Ribeirão Preto ( $21^{\circ} 7^{\prime} \mathrm{S}$ and $47^{\circ} 45^{\prime} \mathrm{W}$ )

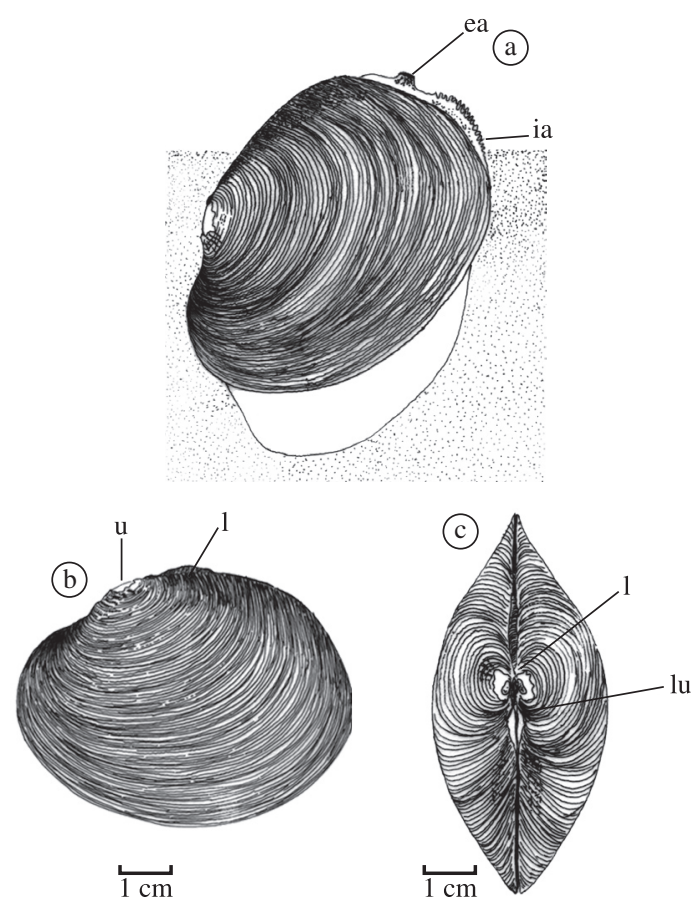

Figure 1. Diplodon r. fontainianus. a) External view of left valve. Live specimen with dark periostracum. ea, exhalant aperture; ia, inhalant aperture. b) Left valve showing growth lines. u, umbo; 1, ligament. c) Dorsal view of valves: 1, ligament; lu, lunule.

and Jardinópolis $\left(21^{\circ} 01^{\prime} \mathrm{S}\right.$ and $47^{\circ} 56^{\prime} \mathrm{W}$ ) both in the state of São Paulo, Brazil (Figure 2). A total of 30 animals were kept alive in the laboratory in aquaria at $25{ }^{\circ} \mathrm{C}$. Some animals were anesthetised with magnesium chloride and were fixed in $10 \%$ buffered formalin for 24 hours. Others were preserved in $70 \%$ alcohol for morphological examination. Shell morphometry was performed according to Mansur et al. (1987). For the anatomical studies, detailed drawings and the arrangement of the internal organs were made using anesthetised animals. Ciliary currents in the mantle, ctenidia, labial palps and stomach were observed under a stereomicroscope, employing carmine or carborundum particles as indicators of current flow. Some structures (palps, ctenidia, mantle and visceral mass) were fixed in aqueous Bouin's fluid, sectioned at 7-10 $\mu \mathrm{m}$ thickness, and stained with Ehrlich's hematoxylin and eosin for anatomical and histological examination.

To investigate the behaviour of the inhalant and exhalent apertures and the arrangement of the tentacles, live animals were held in aquaria and observed under a stereomicroscope.

\section{Results}

Diplodon rhombeus fontainianus was encountered at the edges of the Pardo River, buried in the muddy 
substrate (Figure 1a), especially in shaded localities such as beneath fishing platforms, and among roots and aquatic plants. Various other bivalve species were found at the collection sites, including Corbicula fluminea (Muller, 1774) (an exotic Asian species); D. rotundus gratus (Wagner, 1827); D. greeffeanus, (Ihering, 1893); Anodontites trapesialis (Lamarck, 1819); Castalia undosa undosa (Martens, 1827); and Fossula fossiculifera (Orbigny, 1843).

D. rhombeus. fontainianus and D. greeffeanus were the least frequent species.

Shell: The shell of D. rhombeus fontainianus (Figure $1 \mathrm{~b}$ and $\mathrm{c}$ ) is subcircular, equivalve and inequilateral. The valves are flattened, and the umbo (u) is prosogyrate with a worn periostracum in most adults, owing to the action of abiotic factors. According to Bonetto (1964), the umbonal sculpture appears complete in young animals, with several confluent bars and ribs. The lunule (lu) is small (Figure 1c) and brown. The periostracum is dark brown, with very fine conjoined growth lines; separation of adjacent growth lines is difficult. On the internal face of the shell the nacre is white with clearly visible, light blue stripes and grooves accompanying the pallial line.

The hinge (h) is narrow, and the pseudocardinal tooth of the right valve is double (alt), with internal crenulated faces (Figure 3a). On the left valve, the tooth is simple, the cuspid and external walls being also crenulated; the posterior lateral tooth (plt), is long and consists of two folds in the left valve, whose internal walls are crenu-

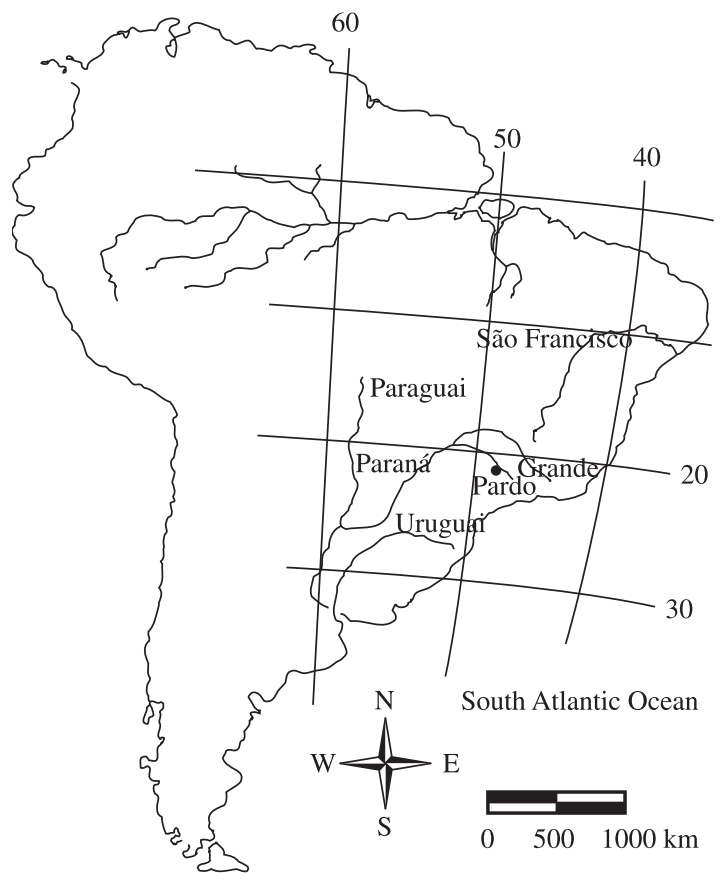

Figure 2. Map of South America:(•) Locality of occurrence of D. r. fontainianus. lated, leaving a recess between the folds for insertion of the posterior lateral tooth of the right valve, which is also long and simple, with crenulated external walls. The umbonal cavity is shallow, and all shells exhibit 3 to 7 small scars with circular contour corresponding to dorsal muscle insertions (dms). The elastic ligament (1) (Figures 1b, c and 3a), with about a third of the shell length is located posteriorly to the umbo, and is very notable, being brown. D. rhombeus fontainianus, like most Hyriidae, is isomiary (Figures 3a, b). The posterior adductor muscle scar (pas) is very pronounced. The round, posterior retractor muscle scar of the foot (prs) is located dorsally in relation to the posterior adductor muscle scar. The anterior adductor muscle scar (aas) is also very pronounced and easily identified. The anterior retractor muscle scar of the foot (ars) is deep and small,
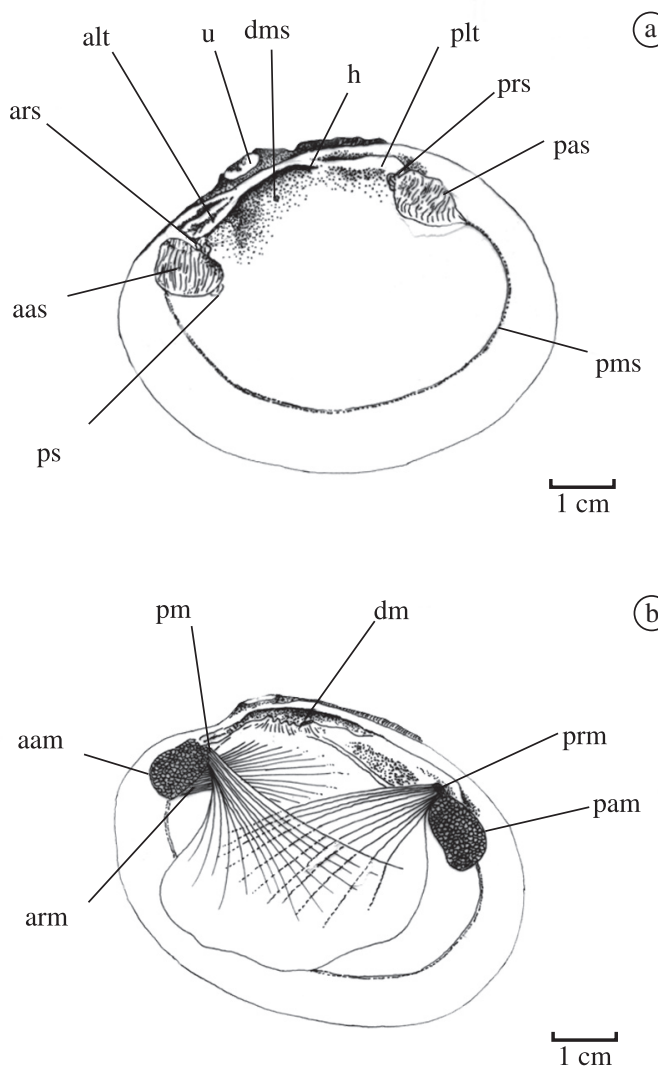

(b)

Figure 3. Diplodon rhombeus fontainianus. a) Internal view of right valve, showing hinge structure and muscle scars. aas; anterior adductor muscle scar; alt, anterior lateral tooth; ars, anterior retractor muscle scar; dms, dorsal muscle scar; pas; posterior adductor muscle scar; plt, posterior lateral tooth; pms, pallial muscle scar; prs; posterior retractor muscle scar; ps; protractor muscle scar, u, umbo. b) Lateral view of right valve musculature after removal of left valve, mantle, palps and visceral mass. aam, anterior adductor muscle; arm, anterior retractor muscle; dm, dorsal muscle; pam, posterior adductor muscle; pm, protractor muscle; prm, posterior retractor muscle. 
circular in contour, and is located below the anterior lateral tooth. The protractor muscle scar of the foot (ps) is small, circular in contour, and located more ventrally in relation to the anterior retractor muscle scar.

Maximum shell length was $70 \mathrm{~mm}$ and the minimum $43 \mathrm{~mm}$, the average value being $52 \mathrm{~mm}$. Maximum shell height was $50 \mathrm{~mm}$ and the minimum $33 \mathrm{~mm}$, the average value being $40 \mathrm{~mm}$. The maximum width was $3.5 \mathrm{~mm}$ and the minimum $1.7 \mathrm{~mm}$; the average value was $2.3 \mathrm{~mm}$

Apertures: The apertures of D. rhombeus. fontainianus (Figure 4a,b) are of the type AII of Yonge $(1948,1957)$. In the inhalant aperture, the inner fold of the mantle presents simple tentacles, disposed irregularly in two arrangements: an outer ring of smaller tentacles, measuring from 0.2 to $0.4 \mathrm{~mm}$ in length, and inner ring of larger tentacles, 0.5 to $1 \mathrm{~mm}$ in length. All tentacles decrease in size as they approach the pedal opening. The exhalent aperture (ea) has no tentacles. It is complete, with black pigmentation in the ventral area. The inhalant aperture is about $0.8 \mathrm{~cm}$ larger than the exhalant aperture in animals about $7 \mathrm{~cm}$ in length.

Organs of the Mantle Cavity: The topography of the principal mantle cavity organs, after removal of the left valve and the left mantle is illustrated in Figure 5a, b.

Mantle: The mantle lobes (Figure 6a) are usually free, except posteriorly where they are joined by their inner folds separating the inhalant from the exhalent aperture. This point of tissue fusion is joined to the poste- rior tips of ctenidia as in D. rotundus gratus (Hebling and Penteado, 1974) and C. undosa undosa (Avelar and Santos, 1991).

The mantle is yellowish. In the posterior region, between the inner and middle folds, typically reduced in freshwater mussels, a black pigmentation delimits the inhalant and exhalent apertures. The ciliary currents on the mantle surface are illustrated in Figure 6b, and are similar to those described by Hebling and Penteado (1974) for D. rotundus gratus, and Hebling (1976) for A. trapesialis and A. trapezeus, and Avelar and Santos (1991) for C.undosa undosa.

Musculature and Foot: In its disposition and insertion on the valve, the musculature of $D$. rhombeus fontainianus is very similar to those of other Hyriidae, as described by various authors, among them Avelar and Santos (1991) (Figure 3b).

The dorsal muscles $(\mathrm{dm})$ range from 3 to 7 in number. These muscles correspond to the elevator muscles of Brück, described for Anodonta cellensis (Schröter, 1779) (Burky, 1983) and by Domaneschi (1995) for the marine tellinoid-semelid mollusk, Semele purpurascens (Gmelin, 1791) and S. proficua (Pulteney, 1799).

The foot of D. rhombeus fontainianus is tongueshaped and light brown, like D. rotundus gratus (Hebling and Penteado, 1974), C. undosa undosa (Avelar and Santos 1991), F.fossiculifera (Avelar, 1992), its epithelium has no cilia.
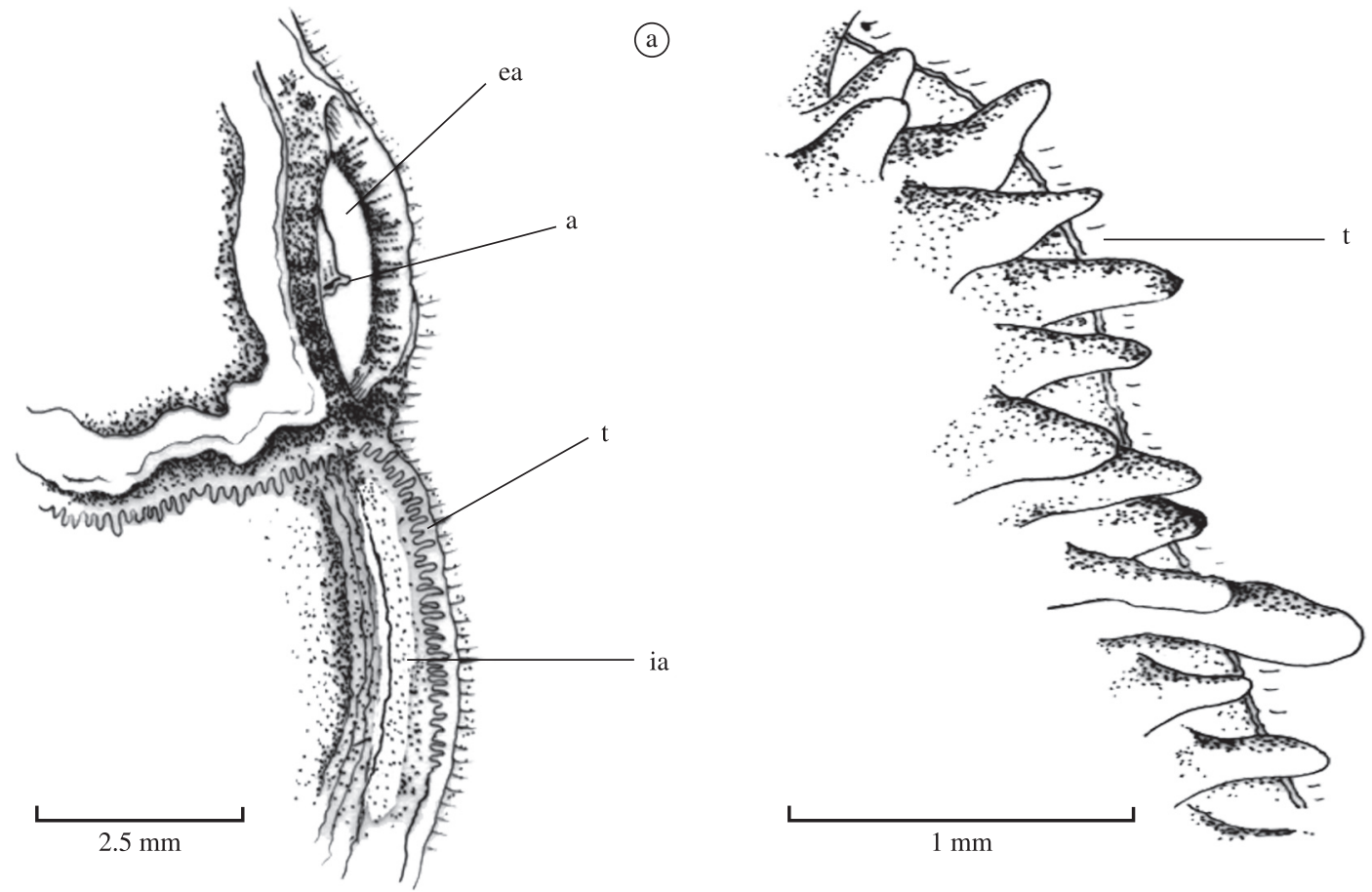

Figure 4. Diplodon rhombeus fontainianus. a) Detailed view of the inhalant and exhalant apertures. a: anus; ea: exhalant aperture; ia: inhalant aperture; t: tentacles and b) deatailed view of the inhalant aperture showing he simple tentacles of the inner ring $(\mathrm{t})$. 

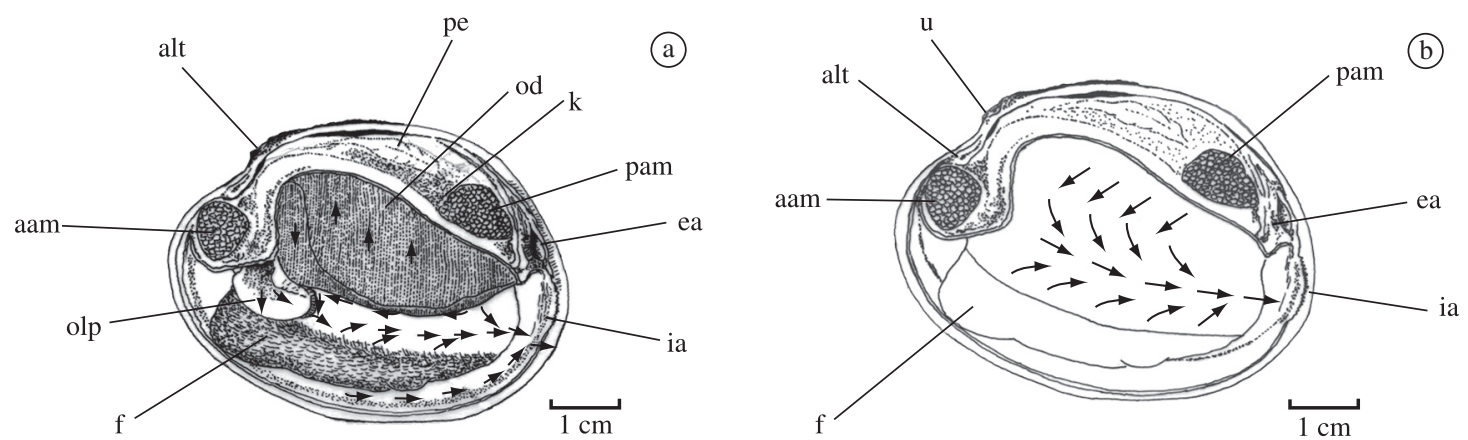

Figure 5. Diplodon rhombeus fontainianus. a) Mantle cavity viewed from left side after removal of left valve and mantle lobe. Arrows indicate the direction of ciliary currents. alt, anterior lateral teeth; aam, anterior adductor muscle; ea, exhalent aperture; ia, inhalant aperture; f, foot; k, kidney; od, outer demibranch; olp, outer labial palp; pam, posterior adductor muscle; pe, pericardium. b) Inner surface of right visceral mass showing ciliary cleansing currents. aam, anterior adductor muscle; alt, anterior lateral teeth, ea, exhalent aperture; f, foot; ia, inhalant aperture; pam, posterior adductor muscle; u, umbo

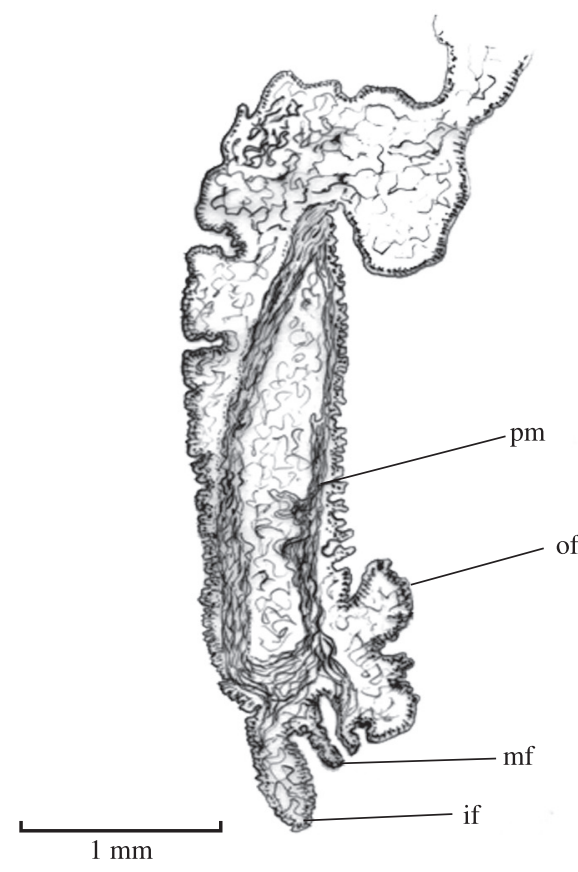

(b)

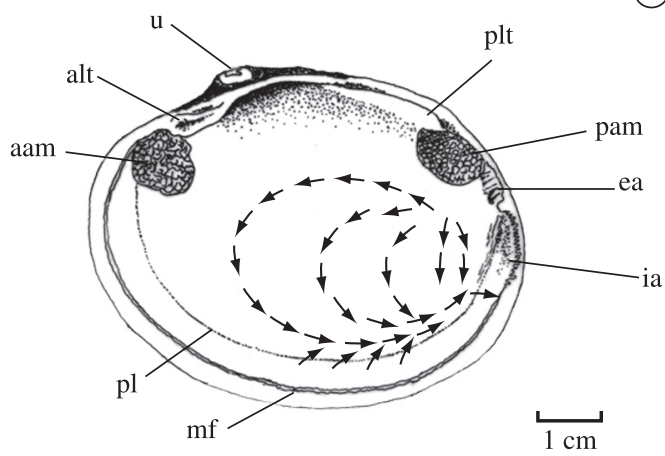

Figure 6. Diplodon rhombeus fontainianus. a) Secction of the mantle showing the marginal folds. If, inner fold; mf, middle fold; of, outer fold; pm, palial muscle. b) Inner surface of right mantle lobe showing ciliary cleasing currents. aam, anterior adductor muscle; alt, anterior lateral teeth; ea, exhalant aperture; ia, inhalant aperture; mf, mantle fold; pam, posterior adductor muscle; pl, pallial line; plt, posterior lateral teeth; u, umbo.
Labial Palps: The labial palps of D. rhombeus fontainianus are symmetrical, rounded in contour with folded free outer and internal faces. The number of folds of their internal faces depends on the size of the animal. In specimens greater than $6.0 \mathrm{~cm}$ long, around 100 fold were present; and in specimens of $5.0 \mathrm{~cm}$ length, there were 80 folds. The internal folds do not reach the ventral edge of the palps, thus leaving a smooth edge.

Several ciliary currents were observed (Figures 7a,b, 1 and 2)

a) A transverse acceptance current;

b) A transverse acceptance current; and

c) A transverse rejection current.

The anatomy of the labial palp folds (Figure 7b) revealed two different canals on their folded faces: one with an acceptance current and the other with a rejection current. On the outer, smooth face of the labial palps, acceptance and/or rejection currents can be seen. The acceptance current reaches the face hidden by the posterior portion of the labial palp, and the rejection current also leads to the posterior region where its particles are discarded.

On the outer face of the outer palps, the rejection currents take the particles to the mantle current. The particles on the outer face of the inner palps are rejected by the ciliary currents of the visceral mass (Figure 6b).

The association between the ctenidia and labial palps belongs to category I of Stasek (1963) in which the anterior filaments of the inner demibranch are inserted but not fused with the anterior canal.

Ctenidia: The ctenidia of D. rhombeus fontainianus (Figure 8a) are type D of Atkins (1937), i. e., characterised by the absence of a marginal groove in the outer demibranch. The ctenidia is typically homorrhabdic, with numerous interlamelar junctions. The inner and outer demibranchs appear slightly pleated, with between 8 to 14 filaments per pleat.

There are three very visible ciliary currents leading in the oral direction. One is located at the junction of the ascending lamella of the outer demibranch (1); one runs along the axis of the ctenidia, between the outer and in- 

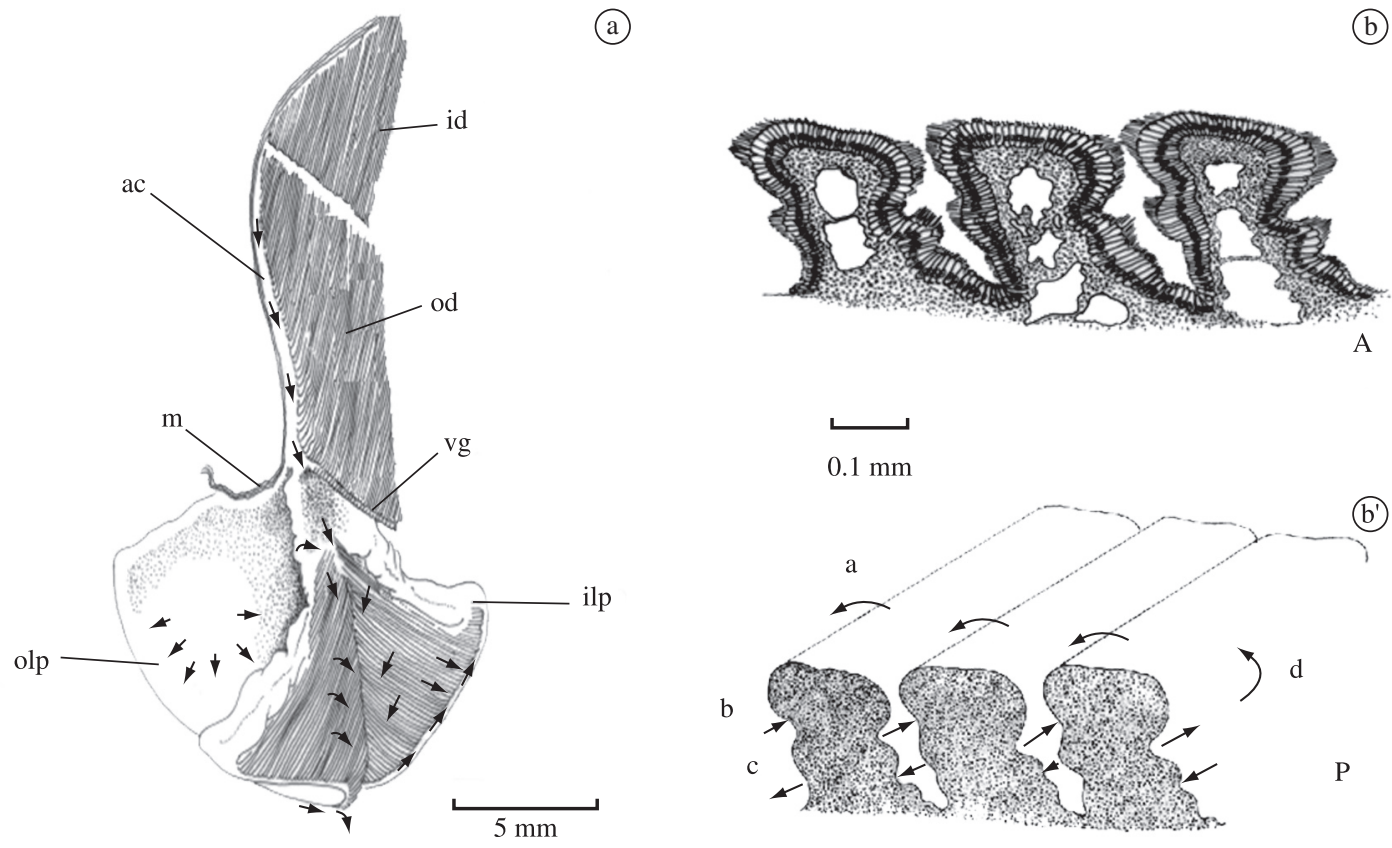

Figure 7. Diplodon r. fontainianus. a) Labial palps on left side; arrows indicate direction of ciliary currents. ac, anterior channel; id, inner demibranch; ilp, inner labial palp; m, mouth; od, outer demibranch; olp, outer labial palp; vg, ventral groove. b) Labial palps. 1, Transversal section showing grooves and ciliation. 2, Schematic representation of labial palps showing ciliary tracts. a, transverse acceptance current in oral direction. b, acceptance current taking the particles from the sub apical posterior area of the folds. c, transverse acceptance current leading to the palps in a deep groove region; $d$, particles are captured by the acceptance current $\mathrm{b}$ to $\mathrm{a}$. A, anterior region; $\mathrm{P}$, posterior region.

ner demibranchs (2); and another in the ventral groove of the inner demibranch (3).

The inner demibranch (id) projects anteriorly to the mantle and visceral mass, and has about 40 filaments more than the outer demibranch in extension and width, attaining some $70 \%$ of the outer demibranch in length. In ovigerous specimens, the typically marsupial nature of freshwater bivalves ctenidia can be seen in the inner demibranch, but the marsupium is visible only during the reproductive phase. In D. rhombeus fontainianus, the marsupium can occupy up to $100 \%$ of the internal cavity of the inner demibranch, depending on the state of release and/or maturation of the eggs.

In the inner demibranch, the particles are carried to the ventral margin on both faces and are selected by weight and/or size. The finer particles are captured by the acceptance current of the marginal groove, on the ventral margin of the inner demibranch, and transported to the labial palps. The heaviest particles drop into the pallial cavity, being captured by the rejection currents of the mantle and eliminated as pseudo-feces in the ventral region of the inhalant opening. In the outer demibranch, on both the inner and outer faces, the ciliary currents take numerous directions and frontal currents direct the particles dorsally to the anterior currents. In the distal portion of the outer demibranch, the acceptance particles may drop onto the anterior portion of the inner demibranch or are sent to the anterior canal and from there to the labial palps, where they are selected. The demibranchs project anteriorly in relation to the mantle and the visceral mass, forming a large and visible anterior canal (ac), originally described by Kellog (1915) as the distal oral channel, which terminates in the labial palps (Figure 7a). A marginal groove of about $200 \mu \mathrm{m}$ in length lies at the free edge of this demibranch, where the particles take on an oral direction. The particles that are guided to the mouth through the marginal groove correspond directly to those of the labial palps. A minor alteration was seen in the ciliation pattern of a small area of the inner demibranch, where the particles may take a ventral direction or drop on the anterior channel. Heavy particles may be rejected and fall on the visceral mass or on the mantle, from where they move to the posterior region and are eliminated through the inhalant aperture. According to Atkins (1938), some variation is likely in the ciliation of different parts of the same filament, although the arrangement is the same along all filaments.

The outer surface of the branchial filaments is covered by the frontal cilia (fc) of $5.8 \mu \mathrm{m}$ in length, and whose beating drives the particles towards the oral currents. The apical area of the inner demibranch filaments exhibits terminal cilia (tc) of $7.3 \mu \mathrm{m}$ in length (Figures 8b,c). These cilia beat obliquely, taking the particles to the anterior region, through the marginal groove 


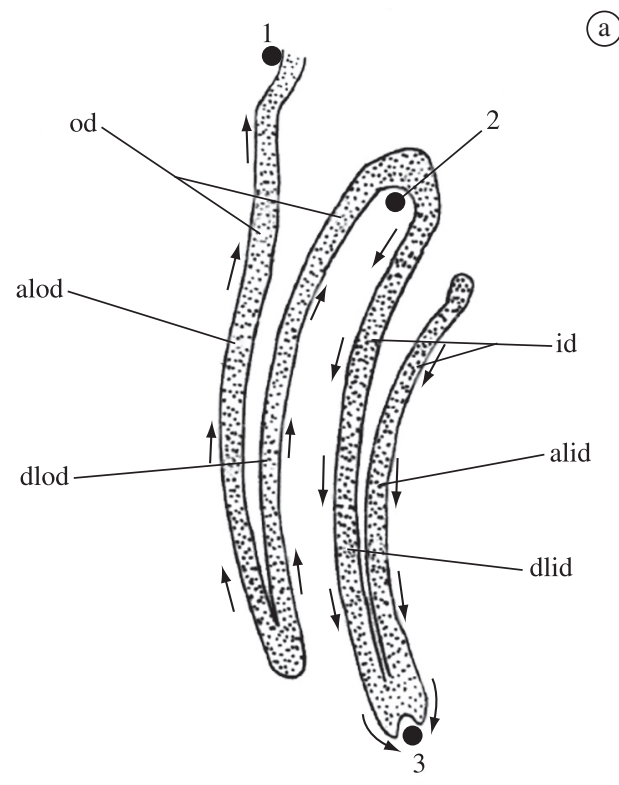

(b)

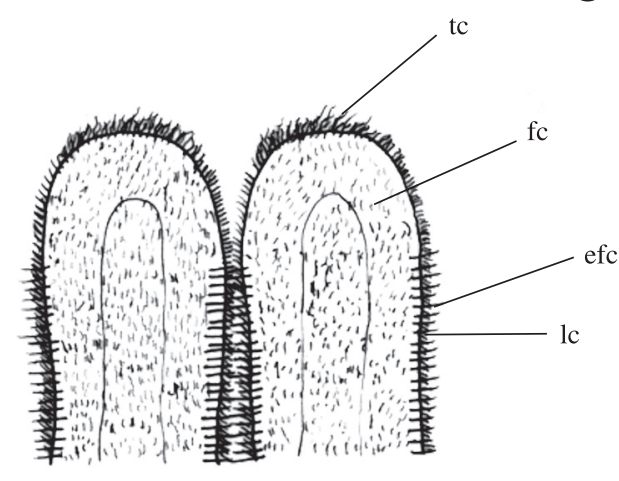

$0.1 \mathrm{~mm}$

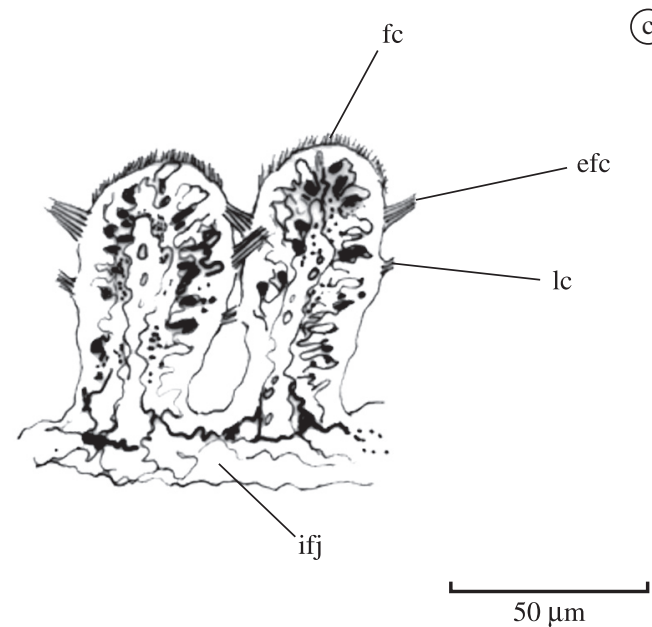

Figure 8. Diplodon $r$. fontainianus. a) Vertical schematic section through ctenidium to show beating direction of frontal cilia. alid, ascending lamella of inner demibranch; alod, ascending lamella of outer demibranch; dlid, descending lamella of inner demibranch; dlod, descending lamella of outer demibranch; id, inner demibranch; od, outer demibranch. 1, 2 and 3, oral currents. b) Frontal view of two filaments showing ciliation. efc, eulatero-frontal cilia; fc, frontal cilia; lc, lateral cilia; tc, terminal cilia. c) Transverse section of two filaments. efc, eulatero- frontal cilia; fc, frontal cilia; lc, lateral cilia; ilj, interfilamentar junction.

of the inner demibranch. Eulatero-frontal cilia (efc) of about $19 \mu \mathrm{m}$ in length can be seen on adjacent filaments, and decrease progressively in length in the direction of the distal region of the demibranch. On each side of the filaments, the cilia beat obliquely, driving the particles to the anterior region through the interfilamentar spaces. The eulatero-frontal cilia of one filament alternate with those of the adjacent filament, forming a network, which impedes the passage of larger particles to the interior of the demibranch. The lateral cilia (lc) of $1.1 \mu \mathrm{m}$ in length appear internally to the eulatero-frontal cilia.
Alimentary Canal: (Figure 9a). The mouth (m) is located in the posteroventral region of the anterior adductor muscle (aam), and appears as an enlarged slit. The esophagus (oe) is flattened and becomes narrower closer to the stomach.

The inner wall possesses grooves and folds that are interrupted by a transverse ridge ( $\mathrm{rm}$ ) at the entrance to the stomach. The stomach (st) is initially globular, and is located in the anterior-medial region of the visceral mass where it is enveloped by numerous ramifications of the digestive diverticula (dd). The style sac (ss) and the mid- 

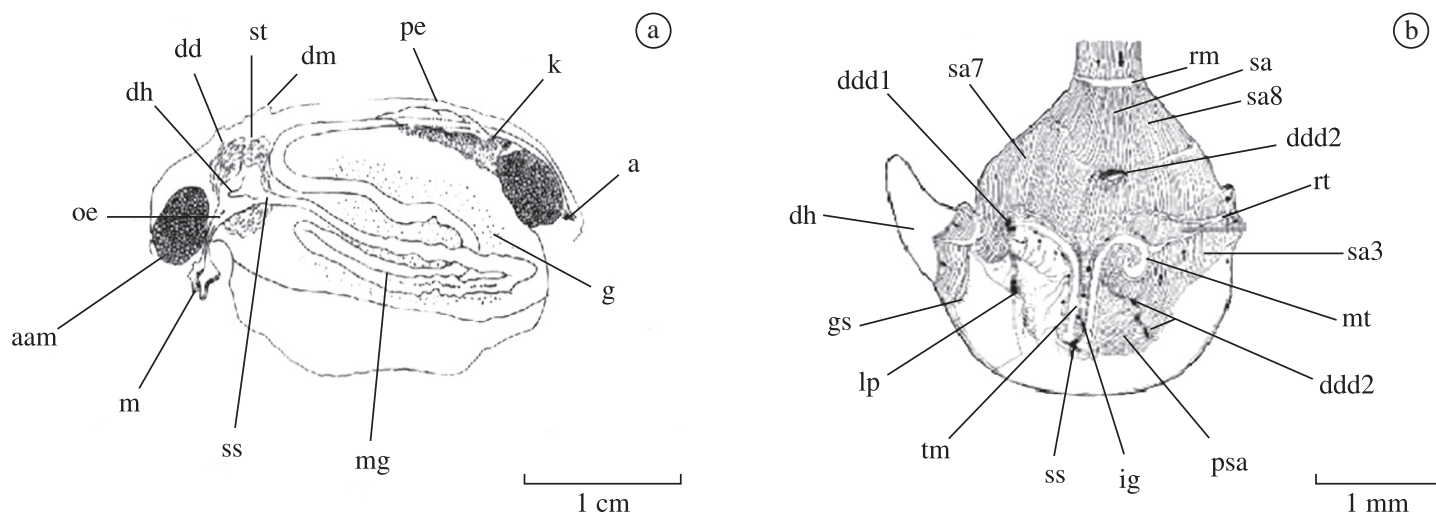

Figure 9. Diplodon $r$. fontainianus. a) View from left side of alimentary canal. a, anus; aam, anterior adductor muscle; dd, digestive diverticula; dh, dorsal hood; dm, dorsal muscle; g, gonads; k, kidney; m, mouth; mg, midgut; oe, esophagus; pe, pericardium; ss, style sac; st, stomach. b) Interior of stomach opened from right side. ddd1, orifice of left duct of digestive diverticulum; ddd2, orifice of right duct of digestive diverticulum; dh, dorsal hood; gs, gastric shield; ig, intestinal groove; lp, left pouch; mt, minor typhlosole; rt, ciliated rejectory tract; sa, anterior sorting area; sa3, main sorting area of dorsal hood; sa7, sorting area below esophageal orifice; sa8, sorting area on anterior roof of stomach; psa, posterior sorting area; $\mathrm{rm}$,transverse ridge; ss, orifice of style sac and midgut; tm, major typhlosole.

gut (mg) leave the stomach at its postero- ventral area and descend into the visceral mass (Figure 9b).

Stomach Structures: The stomach of D. rhombeus fontainianus (Figure 9b) presents characteristics typical of type IV of Purchon (1958) and type C of Dinamani (1967).

In $D$. rhombeus fontainianus, the style sac and the midgut are united and open to the ventral posterior wall of the stomach. The major typhlosole (mt) leaves the opening of the intestine and leads anteriorly to the floor of the stomach, winding gradually to the left, where it penetrates into orifice ddd1. The minor typhlosole (mt) terminates in the right stomach wall.

The gastric shield (gs) is saddle shaped and it does not reach the left pouch. The ducts of the digestive diverticula associated with the left pouch were not easily seen in the material examined.

The following sorting areas were found in D. rhombeus fontainianus: sa, sa3, sa7, sa8, psa. The anterior sorting area (sa) is not well developed and is located anteriorly to the floor of the stomach; it consists of a groove and parallel folds that lead toward the intestinal groove (ig). Sorting area sa 3 is the main sorting area of the dorsal hood (dh); it is located on the right posterior stomach face and leads to the left, terminating inside the dorsal hood. This area is similar to sorting area sa7, located in the anterior area of the stomach floor showing intense ciliary activity and provisioned with fine pleats and grooves. Sorting area sa8 is well developed and consists of a fold in the anterior wall of the stomach, below the esophageal opening.

The posterior sorting area (psa) is also well developed, as in other species of Unionidae like A. cygnea (Reid, 1965). This sorting area leads towards the dorsal hood, where it occupies a small area of the wall limited anteriorly by area sa3. The posterior sorting area (psa) presents two pouches (rp) in D. rhombeus fontainianus.

Ciliary currents: The ciliary currents of the stomach in $D$. rhombeus fontainianus, follow the same general pattern seen in most freshwater bivalves. The food particles that enter the stomach together with the mucous filament are directed to the dorsal hood through ciliary beating in sorting areas sa8 and sa3. The particles in the dorsal hood undergo a selection process and are redirected to the posterior selection area where they are accepted or rejected. Those that are accepted continue to the major typhlosole, or the minor typhlosole where it penetrates into the ducts of the digestive diverticula, on the right or left side of the stomach. The few rejected particles return to the stomach lumen, and continue to the midgut through the intestinal rejection groove (ig).

Pericardium, Kidney, Heart and Gonads: The pericardium (pe), kidney and heart (Figure 6a) are similar to those of other unionids and hyriids examined by various authors such as Hebling (1974) and Avelar (1992). The kidney (k) extends posteroventrally to the pericardium and is similar to that of Anodonta (White, 1942; Yonge, 1978) and C. undosa undosa (Avelar and Santos, 1991).

\section{Discussion}

D. rhombeus fontainianus is a geographically defined subspecies, distributed throughout the States of Minas Gerais, Espirito Santo, Santa Catarina, including the rivers of the upper Paraná basin (Bonetto and Mansur, 1970, Simone, 2006). 
The functional anatomy of $D$. rhombeus fontainianus have revealed the anatomical similarity among species of the families Hyriidae, Mycetopodidae and Unionidae. The adaptations found allow D. rhombeus fontainianus to live in muddy substrates in calm waters, feeding on suspended particles. This adaptive success is a consequence of several factors. The first is the round shell and narrow profile, which allow the animal to bury easily in the mud.

According to Ortmann (1921), the shell shape and hinge structures are diagnostic characteristics of the genus Diplodon, but do not serve to diagnose species. However, adult $D$. rhombeus fontainianus can be easily identified among the other species of Diplodon found in the Pardo river, although such identification is very difficult when the specimens are young.

The general arrangement of the external characteristics of the hinge apparatus of $D$. rhombeus fontainianus follows the description of Hebling and Penteado (1974) for $D$. rotundus gratus. Close examination reveals that the hinge of $D$. rhombeus fontainianus is slightly smaller and narrower than that of $D$. rotundus gratus. This characteristic is a further parameter to distinguish between D. rhombeus fontainianus and D. rotundus gratus.

Tevesz and Carter (1980) investigated the relationship between shell structure and shell-shape in the Unionacea and their environment. According to these authors, shell diameter correlates negatively with water velocity, and positively with river size. D. rhombeus fontainianus has a narrow shell and is always found in areas of moderate currents. The animals collected from the Pardo River show very little variability in shell shape, as also noted by Bonetto and Mansur (1970), who found little variation in shells from rivers discharging into the southern Atlantic in Brazil.

According to Haas (1931), the shell of D. rhombeus fontainianus changes according to the environment inhabited. Haas found differences in the shells of individuals of the same species taken from calmer waters compared to those from stronger currents, with intermediate examples. However, Haas affirms that D. rhombeus fontainianus is unmistakable among the other species of Diplodon, owing to its umbonal characteristics and shell format.

The presence of short cilia in the demibranchs, labial palps, and a stomach adapted to different functions, together with the presence of short, simple tentacles in the non-ramified inhalant aperture all suggest that D. rhombeus fontainianus inhabits calm waters containing fine particles in suspension.

The mantle represents an important area of particle rejection, possessing very efficient cilia that quickly remove particles. These currents are similar to those described for A. trapesialis and A. trapezeus Spix 1827 (Hebling 1976), for D. rotundus gratus (Hebling and Penteado, 1974) and in C. undosa undosa (Avelar and Santos 1991).
The pigmentation noted in the exhalent aperture is similar to that of Diplodon from the Guaíba river, as observed by Mansur (1973). The high sensitivity of the apertures of $D$. rhombeus fontainianus to light, to mechanical stimulation and to small vibrations perceived in its environment, as known for all infaunal or epifaunal bivalves, has already been observed in marine (Narchi, 1974) and South American freshwater mussels (Hebling, 1976; Avelar and Santos, 1991; Avelar, 1992).

The ctenidia in D. rhombeus fontainianus belong to Type D of Atkins (1937), are typically homorrhabdic and eulamellibranch, and are similar to those of Anodonta and Unio, as described by Ridewood (1903). The ciliary currents seen on the ctenidia of $D$. rhombeus fontainianus are similar to those of $D$. rotundus gratus, $C$. undosa undosa, A. trapezeus, A. trapesialis, and F. fossiculifera. According to Atkins (1938), the general ctenidial ciliation of the lamellibranchs is well defined and appears to be conserved among the different species of freshwater mussels.

The demibranchs of $D$. rhombeus fontainianus are large and the labial palps are well developed, presenting an efficient particle sorting mechanism. According to Atkins (1937), species that feed on suspended particles in suspension exhibit large ctenidia and smaller labial palps. Mansur and Anflor (1981) noted more simple palps in D. pilsbryi (Marshall, 1824), which is a mud dweller found in calm waters containing few small suspended particles, compared to D. charruanus (Orbigny, 1835), an inhabitant of coarse sand subjected to moderate water movements.

The type of association between the ctenidia and labial palps proposed by Stasek (1963) is one of the most primitive, and belongs to the Unionacea and to the Nuculacea, superfamilies in which the most primitive bivalves are placed.

According to Yonge (1949), the presence of well-developed labial palps is common in mud-digging bivalves habiting very fine sediments, a fact noted in the present work. The ciliary currents present on the labial palps of D. rhombeus fontainianus are similar to those described by Hebling and Penteado (1974) for D. rotundus gratus, by Hebling (1976) for A. trapesialis and A. trapezeus, and by Avelar and Santos (1991) in C. undosa undosa, all inhabitants of calm waters.

The same muscles described by Bonetto (1963), for Leila blainvilleana Lea 1834, also described by Hebling and Penteado (1974) for D. rotundus gratus, and by Avelar and Santos (1991) in C.undosa undosa seems to be present in most Unionoida studied so far, constituting another primitive character of this superfamily. These muscles exhibit some variation in form and number among specimens of the same size, and even between the right and left sides of the same animal. This has been observed for D. rotundus gratus (Hebling and Penteado, 1974), for A. trapezialis (Hebling 1976) and for C. undosa undosa (Avelar and Santos 1991). 
The organization of the gut in the visceral mass in three loops follows the same pattern seen in the Hyriidae already studied: C. undosa martensi (Mansur, 1972), D.rotundus gratus (Hebling and Penteado, 1974), D. charruanus and D. pilsbryi (Mansur and Anflor, 1981) and C.undosa undosa (Avelar and Santos, 1991). It probably is a feature of South American Hyriidae.

According to Purchon (1958), the type IV stomach is the most primitive and originates stomach types III and V through specialization. The stomach of D. rhombeus fontainianus belongs to type IV of Purchon (1958), and exhibits large and well developed sorting areas. This organ seems to be very efficient in sorting small particles. However, it differs little from the stomachs of the Hyriidae, and greatly from the stomachs of the Mycetopodidae studied so far, except for certain ducts and the size of the sorting areas. Mansur (1973) compared the stomachs of three species of Diplodon from the Guaíba River and found no morphological differences between them. The stomachs of these species also did not differ from that of C. undosa martensi, studied by Mansur (1972). The uniformity of freshwater bivalve stomachs has drawn the attention of Hebling (1976) who noted that this lack of variation may be due to adaptive convergence, since the species showed very few differences, and are identical in practical terms.

The position of the larger typhlosole, as it leaves the opening of the intestine, deviating increasingly to the left and penetrating into the DDD1 has been described by Purchon (1958) for the Unionidae, Chamidae and Gastrochaenidae. Mansur (1972, 1973), Hebling and Penteado (1974), Mansur and Anflor (1981) and Avelar and Santos (1991) also reported the same situation for the Hyriidae they examined. The gastric shield (gs), which does not reach the left pouch (lp), constitutes an exception to this characteristic as seen in the Lucinidae (Purchon, 1958)

Regarding the digestive diverticula associated with the left pouch, Purchon (1958) found a variable number of ducts in 21 families with a type IV stomach, and in Anodonta cygnea Lea only two were found. Mansur (1972) found the same number in C. undosa martensi. Such ducts were not described in the present study, nor in D. charruanus and D. pilsbry (Mansur, 1981), nor in C.undosa undosa undosa (Avelar and Santos, 1991).

The posterior sorting area (psa) is also well developed, as seen in the species of Unionidae examined by various authors (Reid, 1965, Purchon 1958, Dinamani 1967). This area is characterised by the presence of two pouches (rp) in D. rhombeus fontainianus. These pouches were also described in D.charruanus, D.rhombeus fontainianus, D. delodontus wimanii (Mansur, 1973); D. rotundus gratus (Hebling and Penteado, 1974); D. pilsbry, D. charruanus, C. undosa martensi (Mansur and Anflor, 1981) and C.undosa undosa undosa (Avelar and Santos 1991). In D. rhombeus fontainianus and D. charruanus these pouches do not have a tyflossole as in D.pilsbryi described by Mansur and Anflor (1981) and in C. undosa undosa (Avelar and Santos, 1991).

Sorting area sa3, the main area of the dorsal hood, is similar to that described by Dinamani (1967) for Lamellidens corrianus Lea. Purchon (1958) described small pleats in this area in Anodonta cygnea. This sorting area increases the efficiency of particle selection. Sorting area sa8 is well developed and corresponds to the anterior fold described by Dinamani (1967) for L. corrianus. According to Purchon (1958), this area is not well developed in the Unionidae. Thus, the complexity of the selection areas probably represents an adaptation of the animals to life in environments containing abundant fine particles in suspension.The morphology of the kidney and pericardium is similar to that described by Hebling (1976) for A. trapezeus and A. trapesialis, and to that of C. undosa undosa (Avelar and Santos 1991). According the matrix of morphological characters used by Graf and Cummings (2006), for Etherioidea, D. rhombeus fontainianus have inner demibranchs fused to the visceral mass, anterior ends of the inner demibranchs attached to the visceral mass adjacent to the labial palps (Stasek Type I), mantle fused between the incurrent and excurrent apertures and endobranchy, ctenidia with ciliary currents (Atkins Type D). So D. rhombeus fontainianus could be included in the group with D. deceptus, D. chilensis and Castalia. The only difference refers to the marsupium position. Futher phylogenetical studies are been conducted to demonstrate this relationship among the Hyriidae.

Acknowledgements - We thank FAPESP for financial support (grant number 98/05073), Osmar Domaneschi for critical analysis, Maria Cristina Dreher Mansur for identifying the specimens, and Alvaro da Silva Costa for assistance with the fieldwork.

\section{References}

ALVARENGA, LCF. and RICCI, CN., 1977. Variações morfológicas encontradas nas conchas de uma população de Diplodon besckeanus (Dunker, 1849) (Bivalvia: Hyriidae). In Anais do 5 Encontro de Malacologistas Brasileiros. Mossoró, 1977. vol. 4, p. 33-38.

ATKINS, D., 1937. On the ciliary mechanism and interrelationships of lamellibranchs. Quarterly Journal of Microscopical Science, vol. 79, New Series, p. 375-419. (Part III, Types of lamellibranch gills and their food currents).

1938. On the ciliary mechanism and interrelationships of lamellibranchs. Quarterly Journal of Microscopical Science, vol. 80, p. 331-343. (Part V, The pattern of the lateral ciliated cells of the gill filaments of the Lamellibranchia).

AVELAR, WEP. and SANTOS, SCD., 1991. Funcional anatomy of Castalia undosa undosa (Martens, 1827). (Bivalvia: Hyriidae). The Veliger, vol. 34, no. 1, p. 21-23.

AVELAR, WEP., 1992. Funcional anatomy of Fossula fossiculifera (D'orbigny, 1843) (Bivalvia: Mycetopodidae). Amerucam Malacological Bulletin., vol. 10, no. 2, p. 129-138.

BONETTO, AA., 1961. Investigación acerca de las formas larvales en el gênero Diplodon y su aplicación a los estudos 
sistemáticos. Santa Fé: Ministerio de Agricultura/Ganaderia. $48 \mathrm{p}$.

1962. Notas sobre Diplodon charruanus (Orbigny) y Diplodon rhuacoicus (Orbigny). Santa Fé: Ministerio de Agricultura/Ganaderia. p. 35-44. (publicação técnica, vol. 10).

1963. Contribuición al conocimiento de Leila blainvilliana (Lea) (Mollusca: Pelecypoda). Physis, vol. 24, no. 67, p. 11-16.

1964. Las espécies do gênero Diplodon (Mollusca: Unionacea) en los rios de la Pediente Atlantica Sur del Brasil. Physis, vol. 24, no. 68, p. 323-328.

1967. La superfamília Unionacea en la Cuenca Amazonica. In Atas do Simpósio sobre Biota Amazônica. vol. III, p. 63-82.

BONETTO, AA. and MANSUR, MCD., 1970. Las nayades de la cuenca del Guaíba. Acta Zoologica Lilloana, tomo XXVII, p. 241-260.

BURKY, AJ., 1983. Physiological ecology of freshwaters bivalves. Orlando: Academic Press. p. 281-327. (vol. 6, The Molluska).

DINAMANI, P., 1967. Variation in the stomach structure of the Bivalvia. Malacologia, vol. 5, p. 225-268.

DOMANESCHI, O., 1995. A comparative study of the functional morphology of Semele purpurascens (Gmelin, 1791) and Semele proficua (Pulteney, 1799) (Bivalvia: Semelidae). The Veliger, vol. 38, no. 4, p. 323-342.

GRAF, DL. and CUMMINGS, KS., 2006. Palaeoheterodonta Diversity (Mollusca: Trigonioida + Unionoida): What We Know and What We Wish We Knew About Freshwater Mussel Evolution. Zoological Journal of the Linnean Society, vol. 148, no. 3, p. 343-394.

HAAS, VF., 1931. Versuch einer Kritischen Sichtung der südamerikanischen Najaden, II. Senckenbergiana, vol. 13, no. $1 / 6$, p. 1-342.

HEBLING, NJ., 1976. The functional morphology of Anodontites trapezeus (Spix) and Anodontites trapezialis (Lamarck) (Bivalvia, Mycetopodidae). Boletim de Zoologia, São Paulo, vol. 1, p. 265-298

HEBLING, NJ. and PENTEADO, AMG., 1974. Anatomia funcional de Diplodon rotundus gratus (Wagner, 1827) (Mollusca, Bivalvia). Revista Brasileira de Zoologia, vol. 34, p. $67-80$

KELLOG, JL., 1915. Ciliary mechanisms of lamellibranchs with descriptions of anatomy. Journal of Morphology, vol. 26, p. 625-701.

MANSUR, MCD., 1970. Lista dos moluscos bivalves das famílias Hyriidae e Mycetopodidae para o Estado do Rio Grande do Sul. Iheringia, Série Zoologia, vol. 39, p. 33-95.

1972. Morfologia do sistema digestivo de Castalia undosa martensi (Ihering, 1891) (Bivalvia, Hyriidae). Iheringia, Série Zoologia, vol. 41, p. 25-34.
1973. Morfologia do sistema digestivo das espécies do gênero Diplodon Spix, 1827 do rio Guaíba, Rio Grande do Sul (Unionacea, Hyriidae). Iheringia, Série Zoologia, vol. 43, p. $75-90$.

MANSUR, MCD. and ANFLOR, LM., 1981. Diferenças morfológicas de Diplodon charruanus Orbigny, 1835 e Diplodon pilsbryi Marshall, 1928 (Bivalvia: Hyriidae). Iheringia, Série Zoologia, vol. 60, p. 101-116.

MANSUR, MDC., SCHULZ, C., and GARCES, LMMP., 1987. Moluscos bivalves de água doce: identificação dos gêneros do sul e leste do Brasil. Acta Biológica Leopoldensia, vol. 9, no. 2, p. 181-202.

NARCHI, W., 1974. Aspectos ecológicos e adaptativos de alguns bivalves do litoral paulista. Papeis Avulsos Zoologia, vol. 27 , no. 19 , p. $235-262$.

ORTMANN, AE., 1921. South American naiades, a contribution to the knowledge of the fresh water mussels of South America. Memoirs of the Carnegie Museum, vol. 8, no. 3, p. 451-670.

PURCHON, RD., 1958. The stomach in the Eulamellibranchia: stomach type IV. Proceedings of the Zoological Society of London, vol. 131, p. 487-525.

REID, RGB., 1965. The structure and function of the stomach in Bivalve molluscs. Journal Zoology, vol. 147, p. 156-184.

RIDEWOOD, WG., 1903. On the structure of the gills of the Lamellibranchia. Philosophical Transactions of the Royal Society of London, vol. 195, p. 147-284.

SIMONE, LRL., 2006. Land and freshwater molluscs of Brazil. São Paulo: EGB/Fapesp. 390 p.

STASEK, CR., 1963. Synopsis and Discussion of the Association of Ctenidia and Labial Palps in the Bivalvia Mollusca. The Veliger, vol. 6, no. 2, p. 91-97.

TEVESZ, MJS. and CARTER, JG., 1980. Environmental relationships of shell form and structure of Unionacean bivalves. In Skeletal growth of aquatic organisms. New York: Plenum Publishing Corporation. p. 295-322.

WHITE, KM., 1942. The pericardial cavity and the pericardial gland of the Lamellibranchia. Proceedings Malacological Socity of London, vol. 25, p. 37-88.

YONGE, CM., 1948. Formation of siphons in Lamellibranchia. Nature, vol. 161, p. 198-199.

,1949. On the structure and adaptation of the Tellinacea, depositing feeding Eulamellibranchia. Philosophical Transactions of the Royal Society of London, vol. 234, p. 29-76.

1957. Mantle fusion in the Lamellibranchia. Pubblicazioni della Stazione Zoologica di Napoli, vol. 29, p. 151-171.

, 1978. On the monomyarian Acostea rivoli and evolution of the family Etheriidae Bivalvia: Unionacea). Journal of Zoology, London, vol. 184, p. 429-448. 